\title{
Understanding Geographic Information Systems and Global Positioning Systems in Horticultural Applications
}

Ronnie W. H einiger

ADDITIONAL INDEX WORDS. precision farming, yield monitor systems, remote sensing, variable rate technology, GIS, G PS, D G PS

Summary. N ew technologies such as differential global positioning systems (D G PS) and geographical information systems (GIS) are making it possible to manage variability in soil properties and the microenvironment within a field. By providing information about where variability occurs and the patterns that exist in crop and soil properties, DG PS and GIS technologies have the potential of improving crop management practices. Yield monitoring systems linked to D G PS receivers are available for several types of horticultural crops and can be used in variety selection and/ or improving crop management. Precision soil sampling and remote sensing technologies can be used to scout for infestations of insects, diseases, or weeds, to determine the distribution of soil nutrients, and to monitor produce quality by measuring crop vigor. Combined with variable rate application systems, precision soil sampling and remote sensing can help direct fertilizer, herbicide, pesticide, and/ or fungicide applications to only those regions of the field that require soil amendments or are above threshold levels. This could result in less chemical use and improved crop performance. As with any information driven system, the data must be accurate, inexpensive to collect, and, most importantly, must become part of a decision process that results in improvements in crop yield, productivity, and/ or environmental stewardship.

$\mathrm{P}$

roducers recognize that variability exits in almost every aspect of the crop environment and the benefits that could be obtained from managing inputs based on the specific needs of each plant. $\mathrm{H}$ owever, until the advent of positioning systems and computerized data manipulation systems, the time and labor involved in surveying sites, recording yields, and applying inputs made site-specific horticulture impractical. N ew technologies that can pinpoint sites within a field, store and retrieve vast amounts of data, monitor yields on the go, and apply varying rates of fertilizer and chemicals on small areas within the field have ushered in a new era of precision management. Possible benefits to using these technologies include increased efficiency and profits with a decline in the negative environmental impacts of fertilizers and pesticides.

Vernon G. James Research and Extension Center, 207 Research Station Road, Plymouth, N C 27962-9646.

The cost of publishing this paper was defrayed in part by the payment of page charges. U nder postal regulations, this paper therefore must be hereby marked advertisement solely to indicate this fact. 
Spatial variability in the microenvironment within a farm field has been well documented (M cGraw and $\mathrm{H} \mathrm{emb}$, 1994; Pierce et al., 1994). Topography, depth to rock or clay, nutrient levels, pH, crop yield, and a host of other factors have been shown to change within a farm field ( $\mathrm{H}$ einiger, 1996; Sudduth et al., 1996). H istorically, growers have compensated for some of these variables by differential application of fertilizers and cropping practices based on soil characteristics. H owever, as farm size and mechanization increased, the ability of growers to apply specific farming practices to small field areas declined. In fact, in order to maintain maximum productivity, it became more important to apply large amounts of fertilizers and chemicals to the land. Today, as farm input costs increase in respect to crop prices and concerns mount over the damage to water quality and environment from nonpoint source pollution, growers must improve the efficiency of crop production by using sitespecific farming methods.

Therenewed interest in site-specificfarming is the result of new technologies that make it possible for producers to recognize multiple crop production variables within small areas of a field and to customize their management to tho se variables (R obert et al., 1992). These technologies include DGPS, GIS, yield monitors, remote sensing, and variable rate application equipment. DGPS provides $x, y$, and $z$ coordinates which enable a grower to locate his position within the field. When a D GPS receiver is connected to a yield monitor or soil sensor, it is possible to produce field maps showing changing yield or nutrient levels. These maps help identify areas within a field that require attention. Once a problem within the field has been diagnosed, variable rate application equipment can be used to differentially apply inputs to that problem site. This entire system of using technologies and site-specific management to address agricultural problems is known as precision farming.

It is important to recognize that precision farming systems are driven by information collected from the farm field and used in the decision process. As with any information-based system, there are several key concepts which much be understood in order to increase profits by using precision farming techniquesin a horticultural enterprise. First, the information must be accurate. I naccurate information can actually lead to decisions that result in misapplication of inputs and increased costs (Sawyer, 1994; Wollenhaupt et al., 1994). Second, the information must be collected as inexpensively as possible. Information that costs more to collect than the value of the produce cannot possibly improve farm profits. Finally, the grower or farm manager must be ableto usethat information to improve crop management practices, decrease inputs, or to effect some other positive outcome. To effectively manage nutrients, pests, and chemical inputs, within-field variation must be reliably interpreted (Babcock and Blackmer, 1992; Sawyer, 1994). A successful precision farming system incorporates information on variability in soil nutrients, insects, weeds, diseases, plant growth and yield into a decision cycle. The ideal decision cycle collects information, analyzes that information through the interpretation of relationships found among field variables, and then formulatesamanagement response. That management response is then evaluated using within-field yield patterns to determine the impact on output and profit.

Several factors make the use of precision farming systems attractive to fruit and vegetable growers. First, the large amounts of fertilizer and pesticides used in vegetable and fruit production could be decreased through precise knowledge of where a nutrient deficiency or insect infestation exists within the field or greenhouseand the site-specific treatment of that problem. Second, thehigh value of the produce means that gains in yield derived from early treatment of a pest infestation or nutrient deficiency could translate into significantly higher profits. Finally, sitespecific management of nutrients or pests could enhance fruit or vegetable quality, making them more appealing to the consumer. This paper examines the potential applications of precision farming technologies in horticulture, and describes what the decision cycle might look like for each application.

\section{Horticultural applications}

Monitoring yieldS OF HORTICULTURE CROPS. The ability to measure yield from different locations within a field isperhapsthe most exciting and useful precision agriculture tool available. Because yield integrates all of the various factors, environment, genetics and management, that go into producing a crop, yield maps give the agronomist the opportunity to determine which component wasmost limiting (H einiger and B rake, 1996). While automated yield monitoring systems have been used for harvesting grain crops for over 5 years, automated monitors for horticultural crops have only just recently become available. TheH arvestM aster 500 yield monito ring system ( $\mathrm{H}$ arvestmaster, L ogan $\mathrm{U}$ tah), developed primarily for potatoes (Solanum tuber osum L.), tomatoes (Lycoper sicon esculemtum M ill.), onions (Allium cepa L.), etc., uses idler pulleys mounted on load cells to measure the weight of produce flowing 


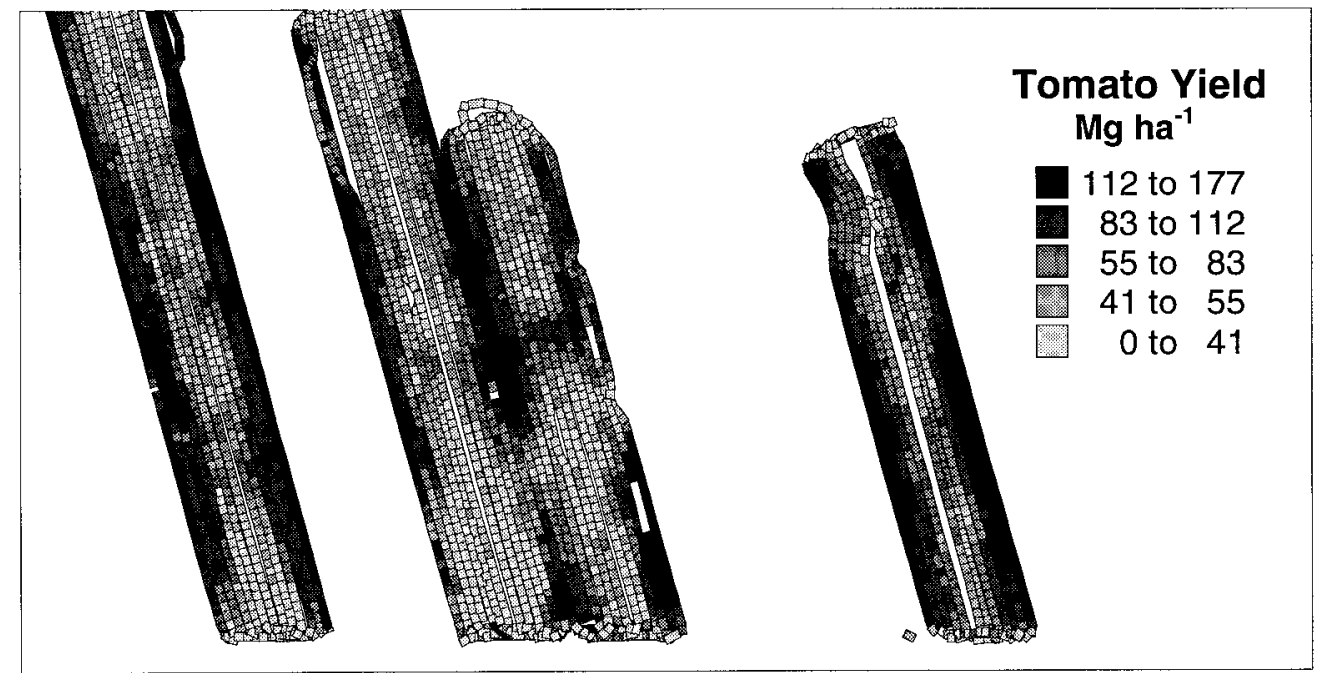

Fig. 1. Yield of tomatoes in a field in eastern North C arolina; $1 \mathrm{Mg}^{\mathrm{M}} \cdot \mathrm{ha}^{-1}=0.446$ tons/acre.

over a chain conveyor running from the digger or picker to the truck or wagon. The monitor takes measurements every second and provides information to the operator about the weight of the produce harvested. When linked to a DGPS receiver, the yield monitor has the capability of producing a map of crop yield within a field (Fig. 1). T ests in potatoes and tomatoes have shown that yields of these crops can be measured with an accuracy of $<2 \%$ (Rawlins et al., 1994).

A nother system for measuring crop yields in horticulture is the use of signal buttons (Agricultural D ata Systems, L aguna N iguel, Calif.) or bar code readers (Brumit, 1997). G rowers can place magnetic markers on fruit trees or in rows of produce which are coded for location as determined by a DGPS receiver. When the fruit is picked from the tree or the row of produce is harvested, an automatic reader is pressed against the button to record the location and then the weight or number of baskets of produce is entered into the system manually. This gives growers who use manual labor the opportunity to record yields based on field location (Fig. 2), the number of baskets or bushels of produce picked by farm labor, and the time that the produce was picked. Such as system could haveimportant uses in tracking producepicked from certain parts of the field all the way to the marketplace.

Yield information can easily become a key tool in a decision cycle for managing horticultural crops. For instance, one of the most important processes in agriculture is evaluating new genetics. Yield information from different genetic materials planted in close proximity can be used to determine which varieties or cultivars to plant in a given environment. Such evaluations have been used for decades on research stations. N ow the same process can be used to refine decisions for an individual farm. Similar in-field trials can be used to evaluate a range of crop management practicesfrom seeding rates and planting dates to fertility applications. I n each situation, different practicescan be applied to strips across the field. Yield information from these strips can be compared using maps which show the differencesbetween thestrips in different areas of the field (Peterson, 1996).

$G$ rowers can then evaluate the success or failure of the practice on different soils or in different situations(Fig. 3). G rowers can also take advantage of the natural variation in soil properties and the resulting differences in crop yield to help them find ways of managing for drought, poor drainage, and nutrient stress. Although the cost of yield monitoring systems is high ( $\$ 7000$ to $\$ 10000$ ), research has shown that small increases in yield can be expected from decisions that result in selecting improved genetics and crop management, and that thesesmall increasesareenough

\section{Strawberry Yields}

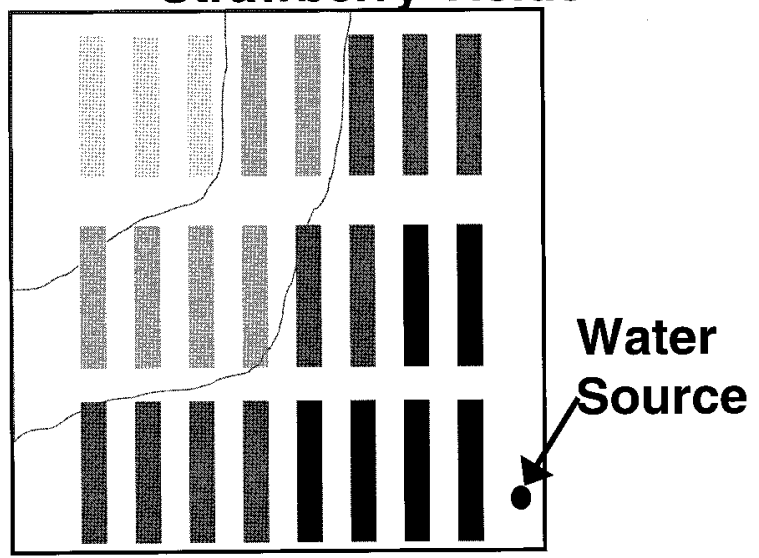

Fig. 2. Strawberry [Fragaria virginiana (L.) Duch.] yield map made by recording yields from beds using magnetic buttons and an electronic recording device. 


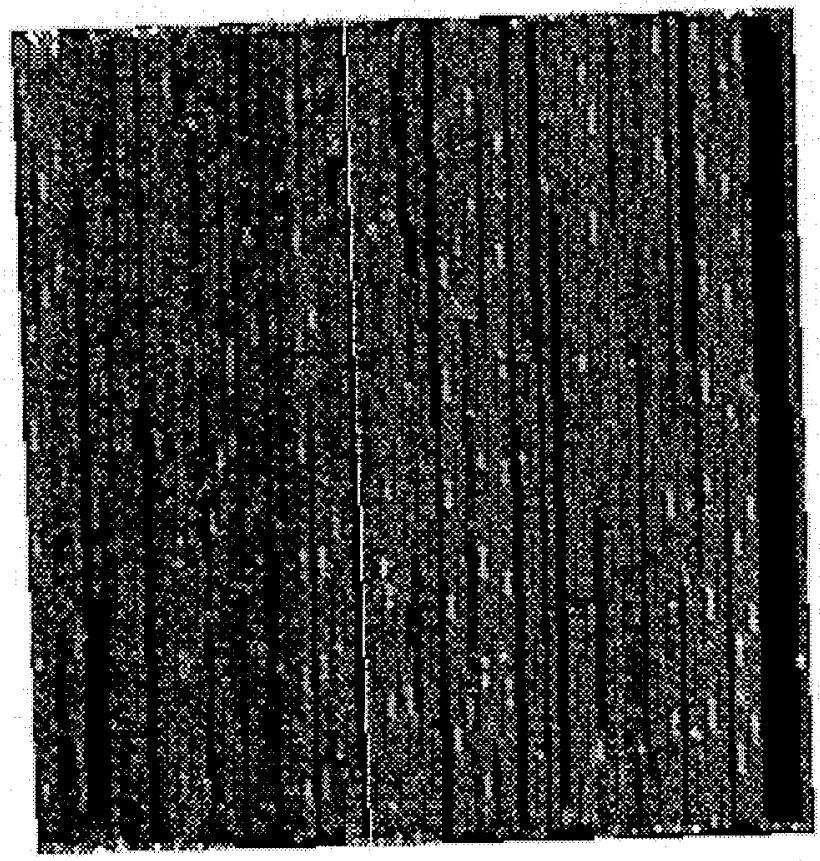

greater than $10.8 \mathrm{Mg} \mathrm{ha}^{-1}$ 10.1 to $10.8 \mathrm{Mg} \mathrm{ha}^{-1}$ 9.4 to $10.1 \mathrm{Mg} \mathrm{ha}^{-1}$ 8.7 to $9.4 \mathrm{Mg} \mathrm{ha}^{-1}$ less than $8.7 \mathrm{Mg} \mathrm{ha}^{-1}$
Yield $9.9 \mathrm{Mg} \mathrm{ha}^{-1}$
Yield $9.3 \mathrm{Mg} \mathrm{ha}^{-1}$
Moisture $16.5 \%$

\author{
Moisture $15.6 \%$
}

Fig. 3. C orn ( $Z$ ea mays L.) yields in 1995 on a 260-ha (640-acre) block on 0 pen $G$ round $F$ arms. The left half of the block has been in continuous no-till while the right half is conventionally tilled using standard

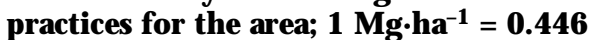
tons/acre.

to pay for the system over a period of 5 to 7 years (H einiger, 1996).

Managing VARIABILITY IN SOIL PROPERTIES. Another precision agriculture tool available to producers growing horticulture crops is the use of D GPS computer-guided soil sampling, often referred to as precision soil sampling. U sing DGPS and GIS technologies, producers can design moreintensive so il sampling schemes to determine the distribution of nutrients in a field. Since soils often vary greatly in nutrient levels, composite soil test results cannot accurately represent all portions of a field. In many cases, composite soil samples mask areas of higher and/ or lower levels of plant nutrients. Precision soil sampling provides information to 1 ) identify localized regions of nutrient deficiencies and excesses within fields, 2) increase lime and fertilizer use efficiency by directing applications to specific sites, and 3) correct nutrient deficiencies on specific soil types.

The first step in the processis to map soil fertility. This is done by using a DGPS equipped all terrain vehicle for collecting the soil samples. This vehicle is used to map the field boundary using the DGPS to provide coordinates. Then the field is divided into grids and soil samples are pulled from each grid. TheD GPS guidance system linked to an on-board computer providestheinformation necessary to determine where the samples are to be taken. O nce the soil sample is taken, its true position is logged into the computer for future reference. The resulting soil samples are tagged with their reference number and sent off for analysis. When the laboratory analysis is received, the data is matched to its location within the field and a contour map is created using oneor moregeostatistical methods (I saaks and Srivastava, 1989). When fertilizer is spread on the field, the spreader uses a computer-guided variable rate technology (VRT) controller to adjust fertilizer application rates on the go. $U$ sing the nutrient map, the computer sets the rate to be applied on the VRT controller according to the position of the spreader in the field. The controller then adjusts the rate at which the fertilizer spreader unloads the material. N umerous companies are now building fertilizer equipment for VRT applications including ruggedized computers, controllers, and software. Costsfor soil sampling equipment (excluding the all-terrain vehicle) run from $\$ 4000$ to $\$ 8000$, and for VRT equipment (excluding the spreader truck) costs range from $\$ 8000$ to $\$ 12000$. M any commercial suppliers for fertilizer materials now offer precision soil sampling and VRT application at prices ranging from $\$ 24$ to $\$ 44 /$ ha ( $\$ 9.70$ to $\$ 17.80$ / acre). 


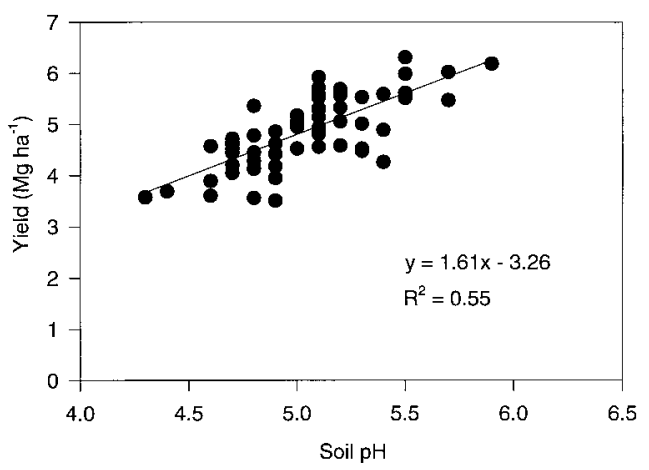

Fig. 4. Linear relationship between wheat (T riticum aestivum L.) yields and $\mathrm{pH}$ devel oped by comparing soil test values with yield data collected from the same location using a yield monitor; $1 \mathrm{M} \mathrm{g} \cdot \mathrm{ha}^{-1}=0.446$ tons/acre.

Intuitively, the application of information gained from precision soil sampling should result in a better match between soil nutrient levels and application rates, and, in the final analysis, should result in better crop yields or lower application rates. H owever, what many are discovering is that increasing soil nutrient levels does not always result in increased yield, even in areas of the field where nutrient levels are low. If soil nutrients are not the limiting factor in crop production, then a yield response to changing nutrient levelsisnot likely. Precision soil sampling will only improve yields and profit if there is an indication that the nutrient or soil property in question is limiting yield. A good example of this is the variability in $\mathrm{pH}$ in soils in $\mathrm{N}$ orth Carolina. Yield maps and precision soil testing indicated a clear relationship between $\mathrm{pH}$ and crop yields (Fig. 4). As a result, VRT applications of lime produced yield gainsthat resulted in a $\$ 25 /$ ha $(\$ 10.17 /$ acre) gain in profit over uniform applications of lime. Likewise, when two years of corn and soybean yields showed patterns that matched field variability in phosphoruslevels (Fig. 5), VRT applications of phosphorus and potassium produced a $\$ 26 /$ ha ( $\$ 10.50 /$ acre) profit when compared to uniform applications (Table 1) (H einiger, 1998). G rowers of horticultural crops can determine the potential for increasing profits through reducing the amount of nutrients applied or by increasing yields by comparing the distribution of soil nutrient levels within a field and examining the relationship between nutrient levels and yield. When themean of the soil nutrient level in the field is greater than the median level found when examining the data from precision soil samples, then the amount of fertilizer applied using VRT methods increases (Fig. 6). In this situation, the grower is de- pending on crop yield increases to return a profit from precision soil sampling. Conversely, when the mean of the soil nutrient level in the field is less than the median level found when examining the data from precision soil samples, then less fertilizer will be applied using VRT methods (Fig. 7). In this case, profitability will depend on how much precision soil sampling costs when compared to the fertilizer saved.

In certain crops, precision nutrient management can improve quality as well as yield. In these situations, profitability is increased by the increased value of the produce. A good example is the use of precision nitrogen $(\mathrm{N})$ management in sugar beets (B eta vulgarisL., C rassa G roup J. H elm) in the R ed River valley between $M$ innesota and North and South D akota (Kerr, 1996). The sugar content of sugar beetsisdirectly related to $\mathrm{N}$ levelsin the plant. $\mathrm{N}$ levels that are too low result in small beets and less tonnage. $\mathrm{N}$ levels that are too high reduce sugar levels in the beets and result in poor quality. Becausenitratelevelsin fields are so variable, it is difficult to apply $\mathrm{N}$ without putting on too much in some spots and too littlein others. By using precision soil sampling to determine changing $\mathrm{N}$ levels within a field, sugar beet growers can apply
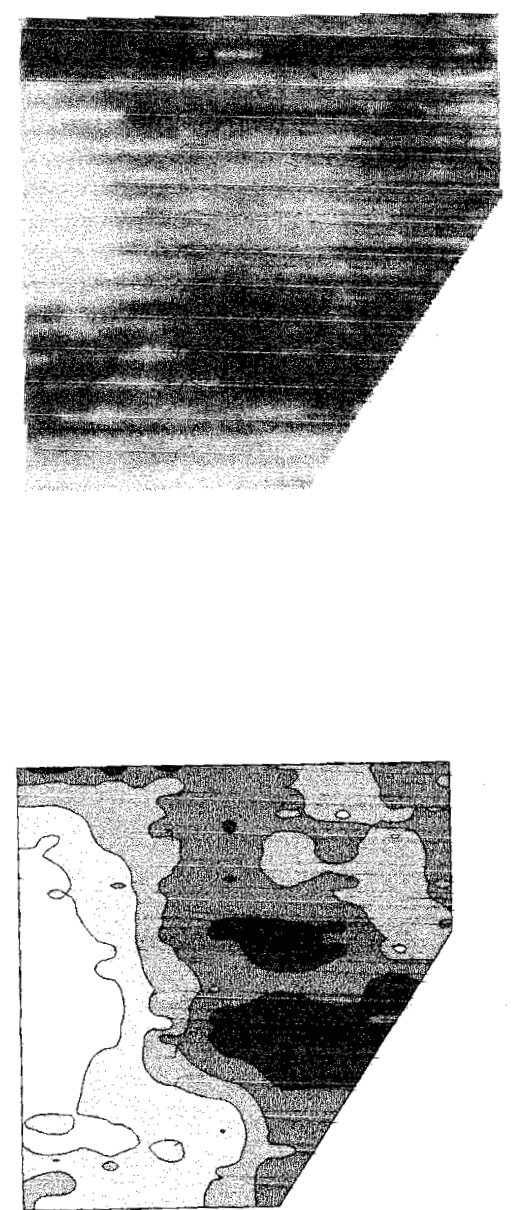

Fig. 5. Map of soybean [Glycine max (L.) Merrill] yield from a 240-ha (640-acre) field and the corresponding phosphorus index for the same field. Index values bel ow 12.5 note very low available phosphorus, while values above 62.5 are excessive; $1{\mathrm{M} \mathrm{g} \cdot \mathrm{ha}^{-1}=}^{-1}$ 0.446 ton/acre. 
T able 1. C ost-profit analysis for variable rate technology (VRT) versus uniform fertilizer application.

\begin{tabular}{|c|c|c|c|}
\hline \multirow[b]{2}{*}{ Operation } & \multicolumn{3}{|c|}{ Cost ( $\$$ for $13.83 h^{2}$ ) } \\
\hline & G rid sample & U niform sample & Difference/advantage \\
\hline Phosphorus & 432.03 & 254.19 & -177.84 \\
\hline Potassium & 265.96 & 251.80 & -14.16 \\
\hline Additional yield income & \multicolumn{2}{|c|}{$\$ 229.44 / \mathrm{Mg} \times 5.98 \mathrm{M} \mathrm{g}^{y}$} & 1371.36 \\
\hline Cost of soil sampling & 239.12 & 68.32 & -170.80 \\
\hline Variable rate spreading & 444.08 & 341.60 & -102.48 \\
\hline Profit $/$ hectare $=\$ 65.51$, & \multicolumn{2}{|c|}{$\begin{array}{l}\text { Profit/ loss to VRT } \\
\text { re }=\$ 26.52\end{array}$} & 906.08 \\
\hline
\end{tabular}

z13.83 ha $=34.17$ acres.

$\mathrm{y} 1 \mathrm{Mg}=1.1$ tons.

the right amount of $\mathrm{N}$ to each area. The result has been an increase in sugar production and quality which has more than paid for the addition cost of precision soil sampling ( $T$ able 2). Such a situation would apply to many horticultural crops where, to a large extent, quality is controlled by plant nutrition.

Precision scouting for Weed, insect, AND DISEASE PROBLEMS. There are many poten-

Fig. 6. Difference between the mean of soil samples collected for the uniform application and the median of the samples collected for variable rate technology (VRT) along with the difference in fertilizer used and cost for phosphorus fertilizer in the form of diammonium phosphate (DAP); 1 ha $=2.47$ acres, $1 \mathrm{~kg}=2.2 \mathrm{lb}$.

\section{Phosphorus Index Frequency}

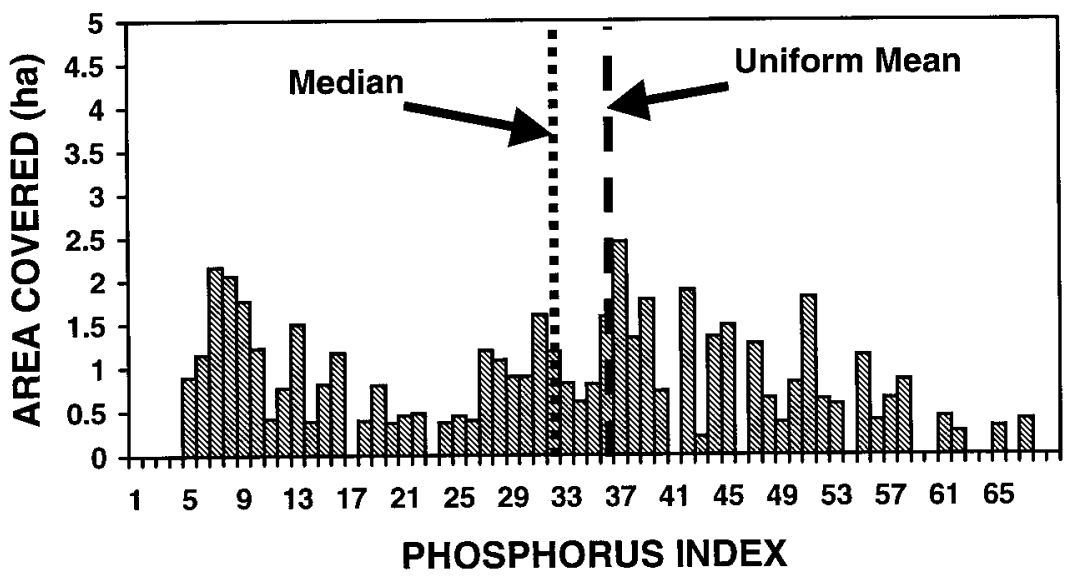

tial uses for precision technologies that are just beginning to be explored. O ne of the most exciting of these is the use of precision tools for scouting weeds, insects, and diseases. Therearenumerousbenefits that could be gained from the identification of weed, insect, or disease patterns within a field and the early application of treatments to those spots (Weisz et al., 1996). First, by identifying spots where weed, insect, or disease levels were above threshold, treatments could be applied early before the problem spreads to other field areas. Second, early treatments are more effectivein controlling pests and pathogens. Third, treatment ratescould betailored to adequately control the levels of pest or pathogen found in a specific area rather than averaged across the field. Fourth, since the areacovered by thetreatment issmaller, there will be less herbicide or pesticide used when compared to treating the entire field. Finally, by only applying materials such as chemical treatments to certain field areas, there is less chance of the pest or pathogen developing resistance to the treatment. Equipment for marking the scouting location and recording data is available in the form of backpack DGPS units which are then connected to small hand-held computers. Software programs written specifically for scouts are used to record the data with links to the coordinates at that location. Costs for this equipment run from $\$ 4000$ to $\$ 10000$.

A good example of the use and benefits of precision scouting and application of chemical treatments comesfrom astudy by Weisz et

\begin{tabular}{|c|c|c|c|c|c|c|}
\hline \multirow[b]{2}{*}{$\begin{array}{l}\text { Available } \\
\text { phosphorus }\end{array}$} & \multirow[b]{2}{*}{$\begin{array}{l}\text { Area } \\
\text { (ha) }\end{array}$} & \multicolumn{2}{|c|}{ VRT sample } & \multicolumn{2}{|c|}{ Uniform sample } & \multirow[b]{2}{*}{$\begin{array}{c}\text { Difference } \\
\text { (\$) }\end{array}$} \\
\hline & & $\begin{array}{l}\text { DAP } \\
\text { (kg) }\end{array}$ & $\begin{array}{c}\text { T otal cost } \\
(\$)\end{array}$ & $\begin{array}{l}\text { DAP } \\
\text { (kg) }\end{array}$ & $\begin{array}{c}\text { T otal cost } \\
(\$)\end{array}$ & \\
\hline Very low & 3.48 & 969.6 & 261.59 & 237.1 & 63.96 & -197.63 \\
\hline Low & 1.79 & 334.0 & 90.11 & 121.9 & 32.88 & -57.23 \\
\hline M edium & 3.36 & 261.0 & 70.40 & 228.9 & 61.75 & -8.65 \\
\hline $\mathrm{H}$ igh & 2.96 & 36.8 & 9.93 & 201.7 & 54.41 & 44.48 \\
\hline Very high & 1.68 & 0 & 0 & 114.5 & 30.89 & 30.89 \\
\hline Excessive & 0.56 & 0 & 0 & 38.2 & 10.30 & 10.30 \\
\hline Total & 13.83 & 1601.4 & 432.03 & 942.3 & 254.19 & -177.84 \\
\hline
\end{tabular}


al. (1996). U sing customized scouting methods, infestations of colorado potato beetle (Leptinotarsa decimlineata Say) weremapped treatments were applied differentially across the field. These techniques reduced chemical use from $40 \%$ to $70 \%$ with no reduction in potato yield or quality, and there was a reduction in the rate at which theinsects develo ped resistance to the chemical treatments. $\mathrm{H}$ owever, one problem with using this technique for scouting pest infestations is that it is extremely time consuming and difficult to use. Q uicker and more simplified procedures must be developed before precision insect management can be used on a large scale.

O ne method of reducing the time and expense of scouting weeds, insects and diseases is the use of infrared images. Infrared photographs are commonly used in several states to scout for weeds, diseases, and insects. Infrared images taken on a regular schedule can help thegrower identify changes within the field that can be indicators of pests or pathogens ( $\mathrm{N}$ ichols, 1997). Remote sensing technologies such as infrared images help identify problem areas quicker and result in more timely treatment applications.

Managing QUalitY WTH ReMOTE SENSING. Remote sensing can also be used to manage the quality of the produce. By monitoring crop vigor and health, growers can take steps to control quality within a field. Because quality is an important factor in marketing produce, the benefits of managing produce quality within a field can be substantial. A good example of this type of application comes from studies done on vineyards in California (Lang, 1997). The sugar content of the grape (Vitisvinifera L.) is related to the vigor of the vine. Remote sensing is being used to identify areas within the vineyard where excessive growth is occurring. By controlling nutrients and/ or water, growth can be regulated in certain areas of the vineyard resulting in a more uniform product and high quality wine.

Remote images have been used to measure tree growth in orchards which is directly in a potato field. $U$ sing these maps, chemical related to fruit production. By differentially applying nitrogen based on the growth of the

individual tree, better quality, more uniform fruit can beharvested. Potentially, thesetechnologies when combined with yield mapping and coded tags can be used to track produce all the way from the field to the market. This information could help determine soil and environmental factors that result in better quality and longer shelf life.

Managing greenhouse production. GIS, hand-held data recorders, and VRT applicationscan also beimportant toolsin managing large-scale greenhouse production. $M$ aps of the greenhouse showing the location of fans, heaters, shading patterns, etc. can be valuable in determining areas within the greenhouse where insect or disease infestations begin. By monitoring the plants and recording the monitoring locations, greenhouse managers can develop information on insect and disease patterns along with plant growth problems. This could be used to adjust monitoring procedures, reducechemical applications, and improve greenhouse designs. In greenhouse situations, DGPS equipment would

Fig. 7. Difference between the mean of soil samples collected for the uniform application and the median of the samples collected for variable rate technology (VRT) along with the difference in fertilizer used and cost for potassium fertilizer in the form of potash (0-0-60). 1 ha $=2.47$ acres, $1 \mathrm{~kg}=$ $2.2 \mathrm{lb}$.

\section{Potassium Index Frequency}

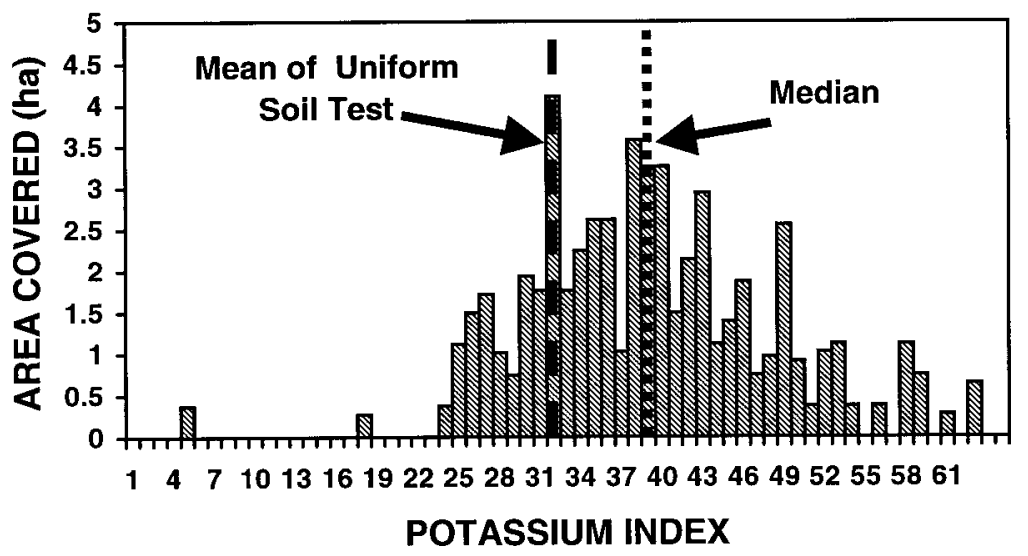

VRT sample

\begin{tabular}{lc}
$\begin{array}{l}\text { Available } \\
\text { potassium }\end{array}$ & $\begin{array}{c}\text { Area } \\
\text { (ha) }\end{array}$ \\
\hline Very low & 0 \\
Low & 1.74 \\
M edium & 6.88 \\
H igh & 5.09 \\
Very high & 2.09 \\
Excessive & 0 \\
Total & 15.80
\end{tabular}

Horllechnology • O ctober-D ecember 1999 9(4) 
T able 2. C omparison between site-specific and conventional nitrogen management on sugar beets for yield, recoverable sugar, sugar quality, and profit (Kerr, 1996).

\begin{tabular}{|c|c|c|c|c|c|}
\hline Technique & $\begin{array}{c}\text { Sugar } \\
(\%)\end{array}$ & $\begin{array}{c}\text { Sugar lost } \\
\text { to molasses } \\
(\%)\end{array}$ & $\begin{array}{c}\text { Yield } \\
\left(\mathrm{Mg}^{-h^{-1}}\right)\end{array}$ & $\begin{array}{c}\text { R ecoverable } \\
\text { sugar } \\
\left(\mathrm{kg}^{\prime} \cdot \mathrm{ha}^{-1}\right)\end{array}$ & $\begin{array}{l}\text { G ross } \\
\text { return } \\
\text { (\%/ha) }\end{array}$ \\
\hline G rid sampled variable rate $\mathrm{N}$ & 14.9 & 1.434 & 6.60 & 6277 & 1711.71 \\
\hline Conventionally sampled uniform Rate $\mathrm{N}$ & 14.8 & 1.70 & 43.86 & 5747 & 1528.93 \\
\hline D ifference & 0.1 & 0.27 & 2.74 & 530 & 182.78 \\
\hline \multicolumn{6}{|c|}{$\begin{array}{l}\text { Cost of variable nitrogen application and grid soil sampling }=\$ 56.81 / \text { ha }(\$ 23.00 / \text { acre }) \\
\mathrm{N} \text { et return to variable rate application }=\$ 125.97 / \text { ha }(\$ 51.00 / \text { acre })\end{array}$} \\
\hline
\end{tabular}

z1 $\mathrm{M} \mathrm{g} \cdot \mathrm{ha}^{-1}=0.446$ ton/ acre

y1 $\mathrm{kg} \cdot \mathrm{ha}^{-1}=0.892 \mathrm{lb} /$ acre.

$\times \$ 1 /$ ha $=\$ 0.41 /$ acre.

not be necessary since location could be determined based on the distance and direction from reference points located within the greenhouse itself. Therefore, the cost of collecting information on the spatial patterns associated with insect or disease infestations would be less expensive.

\section{Conclusions}

Technologies such as D GPS, GIS, yield monitors, and remote sensing can provide the growers of horticultural crops information on crop yields and yield limiting factors. This information can be used to improve management practices and increase yield. $\mathrm{H}$ owever, there are several problems that must be solved before precision technologies can become standard in horticultural operations. First, growers must be trained in using satellite and computer technologies. M ost growers do not have the computer skills necessary to use the hardware asso ciated with yield monitors, precision soil sampling, or remote sensing, nor can they manipulate geographic information to give them the answers to the questions they are asking. Second, techniquesfor using GPS and GIS in scouting nutrient deficiencies and pest infestations are extremely time consuming, difficult to use, and costly. Accurate information must be collected in an efficient and inexpensive manner. Procedures for scouting horticultural crops will need to be developed. Finally, there is a need for decision support systems which help the grower identify the most limiting factor at each field site and to determine what steps he needs to take to correct the problem. These problems can be solved through research into precision agriculture and from the development of improved hardware and software specific to horticulture systems.

Despite these obstacles, precision management in horticulture will grow as the cost of inputs increase, as nutrient and environmental regulations increase, as the demand for high quality food increases, and as the need for improved efficiency and understand- ing in the production of horticulture crops increases. Tomorrow's grower will use these technologies and techniques to farm smarter. 0 ur challenge is to find ways to help growers adopt these technologies through an improved understanding of the technologies and techniques behind successful site-specific production systems.

\section{Literature cited}

Babcock, B.A. and A.M. Blackmer. 1992. The value of reducing temporal input nonuniformities. J. Agr. Res. E con. 17(2):335-347.

Brumit, J.A. 1997. N ew technologies for labor management, p. 43. In R.W. K riz (ed.). Proc. 12th Annu. S.E. Veg. and Fruit Expo., Greensboro, N .C., 15-17 D ec. 1997. N .C. Veg. GrowersAssn. Raleigh, N.C.

H einiger, R.W. 1996. The N orth Carolina precision farming project: $M$ anaging crop production with precision technologies using on-farm tests, $p$. 171-178. In P.C. Robert et al. (eds.). Precision agriculture systems. 3rd Intl. Conf. on Precision Agr. M inneapolis, M inn., 23-26J une1996. ASACSSA-SSSA, M adison, Wis.

H einiger, R.W. 1998. Variable rate nutrient management for corn-wheat-soybean cropping systems. B etter C rops with Plant F ood 82(4):11-13.

H einiger, R.W. and S.R. B rake. 1996. Large-scale precision farming: Balancing the books and the environment. Precision farming (Suppl.), GPS World M ag. 4:18-22.

I saaks, E.H . and R.M. Srivastava. 1989. An introduction to applied geostatistics. Oxford U niv. Press, N ew York.

Kerr, M.C. 1996. A sweeter harvest in the Red River valley. Precision farming (Suppl.), GPSW orld $M$ ag. 5:21-25.

Lang, L. 1997. U se of GIS, GPS, and remote sensing spread to California's winegrowers. M odern Agr.: J. Site-specific Crop M gt. 1(2):12-16.

M cGraw, T. and R. H emb. 1994. The amount of variability of fertility in the $M$ innesota river valley watershed in 1993 as determined from grid testing results on $52,000^{+}$acres in commercial fields, $p$. 167-174. I n P.C. Robert et al. (eds.). Site-specific 
management for agricultural systems. 2nd Intl. Conf. Site-specific M gt. for Agr. Systems, M inneapolis, M inn. 27-30 M ar. 1994. ASA-CSSASSSA, M adison, Wis.

Nichols, C. 1997. Satellite imagery: An advanced diagnostic tool for crop scouts using GPS. M odern Agr.: J. Site-specific Crop M gt. 1(3):19-20.

Peterson, T.A. 1996. Conducting on-farm strip tests with a yield monitor. Crop Insights 6(7). Pioneer $\mathrm{H}$ i-Bred Intl., Des M oines, I owa.

Pierce, F.J., D.D. Warncke, and M.W. Everett. 1994. Yield and nutrient variability in glacial soils of M ichigan, p. 133-150. In P.C. Robert et al. (eds.). Site-specific management for agricultural systems. 2nd Intl. Conf. Site-specific M gt. Agr. Systems, M inneapolis, M inn., 27-30 M ar. 1994. ASA-CSSA-SSSA, M adison, Wis.

Rawlins, S.L., G.S. Campbell, R.H. Campbell, and J.R. H ess. 1994. Yield mapping of potato, p. 59-68. In P.C. Robert et al. (eds.). Site-specific management for agricultural systems. 2nd Intl. C onf. Site-specific M gt. for Agr. Systems. M inneapolis, M inn., 27-30 Mar. 1994. ASA-CSSASSSA, $M$ adison, $W$ is.
Robert, P.C., R.H . Rust, and W.E . Larson. 1992. Soil-specific crop management. Research and D evelopment I ssuesWorkshop. M inneapolis, M inn., 14-16 Apr. 1992. U niv. of M inn., M inneapolis.

Sawyer, J.E. 1994. Concepts of variable rate technology with considerations for fertilizer application. J. Prod. Agr. 7:195-201.

Sudduth, K.A., N.R. Kitchen, D.F. H ughes, and S.T. D rummond. 1994. Electromagnetic induction sensing as an indicator of productivity on claypan soils, p. 671-681. In P.C. Robert et al. (eds.). Site-specific management for agricultural systems. 2nd Intl. Conf. Site-specific M gt. for Agr. Systems, M inneapolis, M inn. 27-30 M ar. 1994. ASA-CSSA-SSSA, M adison, $W$ is.

Weisz, R., S.J . Fleischer, and Z. Smilowitz. 1996. Site-specific integrated pest management for high value crops: I mpact on potato pest management. J. Econ. Entomol. 9:501-509.

Wollenhaupt, N.C., R.P. Wolkowski, and M.K. Clayton. 1994. M apping soil test phosphorusand potassium for variable-rate fertilizer application. J . Prod. Agr. 7:441-448. 